\title{
Dexamethasone inhibits paclitaxel-induced cytotoxic activity through retinoblastoma protein dephosphorylation in non-small cell lung cancer cells
}

\author{
MASATO MORITA, HISASHI SUYAMA, TADASHI IGISHI, YASUSHI SHIGEOKA, MASAHIRO KODANI, \\ KIYOSHI HASHIMOTO, KENICHI TAKEDA, TAKASHI SUMIKAWA and EIJI SHIMIZU
}

Division of Medical Oncology and Molecular Respirology, Faculty of Medicine, Tottori University, Yonago 683-8504, Japan

Received July 24, 2006; Accepted September 18, 2006

\begin{abstract}
Paclitaxel is used frequently for the treatment of patients with non-small cell lung cancer. Hypersensitivity reactions remain one of the major adverse events in the clinical use of paclitaxel. Glucocorticoids are used to prevent these adverse events. This study was carried out in order to clarify the effect of glucocorticoids on paclitaxel-induced cytotoxity of cancer cells. Pretreatment with $10 \mu \mathrm{M}$ of dexamethasone inhibited ERK activation and subsequent retinoblastoma protein (pRB) phosphorylation, and reduced sensitivity to paclitaxel in A549 cells. Then, we utilized ERK (PD98059) and AKT (LY294002) inhibitors. PD98059 and LY294002 effectively suppressed pRB phosphorylation in A549 cells. Dexamethasone $(10 \mu \mathrm{M})$ suppressed ERK activity as well as PD98059, although it did not affect AKT activity. Furthermore, the combinations of paclitaxel with PD98059 or LY294002 were similarly antagonistic. Our observation in this study raised the possibility that dexamethasone pretreatment antagonizes paclitaxel-induced cytotoxicity through ERK suppression and pRB dephosphorylation. These observations support the development of new generation taxane-based chemotherapy without glucocorticoid premedication.
\end{abstract}

\section{Introduction}

Lung cancer is now one of the most common causes of cancerrelated death throughout the world $(1,2)$. Although platinumbased chemotherapy remains the cornerstone of treatment for the NSCLC subtype, it results in a small improvement in survival compared with supportive care alone $(1,3)$. Recently, newer chemotherapeutic agents such as taxanes, vinorelbine, gemcitabine and irinotecan have become clinically available to NSCLC.

Correspondence to: Dr Hisashi Suyama, Division of Medical Oncology and Molecular Respirology, Faculty of Medicine, Tottori University, Yonago 683-8504, Japan

E-mail: suyamahi@grape.med.tottori-u.ac.jp

Key words: non-small cell lung cancer, paclitaxel, dexamethasone, retinoblastoma
Among these newer drugs, paclitaxel is the one used frequently for the treatment of patients with NSCLC. The mechanism of cell death induced by paclitaxel is not entirely clear, but it is widely thought that the major cellular target for paclitaxel is the tubulin/microtubule system in mitosis (4). In the clinical use of paclitaxel, hypersensitivity reactions are one of the major adverse events, and glucocorticoids, including dexamethasone, are used to prevent these side-effects (5-7). Because glucocorticoid premedication is routinely used in treatment with paclitaxel, it is important to evaluate its effect on the paclitaxel-induced cytotoxity of cancer cells to improve the effectiveness of paclitaxel-based chemotherapy.

Glucocorticoids are regulatory molecules that control metabolism, development, inflammation, cell growth, proliferation, and differentiation (8). Furthermore, glucocorticoids are known to exert antiproliferative effects in a number of different tissues and cell types resulting in G1 cell cycle arrest and/or apoptosis (8-13).

Retinoblastoma protein (pRB) is a key regulator of cell cycle progression $(14,15)$, and its phosphorylation is essential for S-phase entry from G1 phase in the cell cycle (16). In the previous study, we reported that $\mathrm{pRB}$ phosphorylation status and the cell cycle progression during paclitaxel treatment are important determinants of sensitivity to paclitaxel in NSCLC cells (17). Since glucocorticoid itself affects proliferation of cancer cells (8-13), drug interaction between paclitaxel and glucocorticoid may be possible through the modification of pRB phosphorylation status by glucocorticoid.

Accordingly, we hypothesized that pretreatment of NSCLC cells with dexamethasone may affect the sensitivity to paclitaxel. To address this issue, we investigated the effects of dexamethasone pretreatment on the paclitaxel-induced cytotoxity in relation to $\mathrm{pRB}$ phosphorylation status and its upstream regulators using A549 lung adenocarcinoma cells.

\section{Materials and methods}

Chemicals and reagents. Paclitaxel (a gift from Bristol-MyersSquibb, Inc., Tokyo, Japan); 2'-Amino-3'-methoxyflavone (PD98059) (Calbiochem, San Diego, CA, USA) and 2-(4Morpholinyl)-8-phenyl-4H-1-benzopyran-4-one (LY294002) (Sigma-Aldrich Japan, Tokyo, Japan), was dissolved in dimethylsulfoxide and stored at $-20^{\circ} \mathrm{C}$. 3-(4,5-dimethylthiazol-2-yl)-2,5-diphenyltetrazolium bromide (MTT) 
(Sigma Chemical Co., St. Louis, MO, USA) was dissolved in phosphate-buffered saline (PBS) and stored at $-20^{\circ} \mathrm{C}$.

Cells. The human NSCLC cell line, A549 cells, was maintained in Dulbecco's modified Eagle's medium (DMEM) supplemented with $10 \%$ fetal calf serum (FCS) and antibiotics. The cells were grown in a humidified atmosphere of $5 \% \mathrm{CO}_{2}$ $95 \%$ air.

Cell lysis, immunoprecipitation, and Western blot analysis. Cells were lysed in a modified radioimmune precipitation buffer ( $1 \%$ Triton $\mathrm{X}-100,0.1 \%$ SDS, $0.1 \%$ sodium deoxycholate, $100 \mathrm{mM} \mathrm{NaCl}, 10 \mathrm{mM}$ Tris-HCl, pH 7.5, $2 \mathrm{mM}$ EDTA, $10 \mu \mathrm{g} / \mathrm{ml}$ leupeptin, $1 \mathrm{mM}$ phenylmethylsulfonyl fluoride, $10 \mathrm{mM} \mathrm{NaF}, 40 \mathrm{mM}$ B-glycerophosphate, and $2 \mathrm{mM}$ $\mathrm{Na}_{3} \mathrm{VO}_{4}$ ), and insoluble material was removed by centrifugation. Protein concentration was determined by means of a Bio-Rad Protein assay (Bio-Rad, CA) and lysates containing $50 \mu \mathrm{g}$ of total cellular protein or immunoprecipitates with indicated antibodies were analyzed by Western blotting after SDS-polyacrylamide gel electrophoresis and visualized by enhanced chemiluminescence detection (Amersham Pharmacia Biotech) using goat anti-rabbit IgGs coupled to horseradish peroxidase as a secondary antibody (Amersham Pharmacia Biotech). Antibody against pRb (IF8) was purchased from Santa Cruz Biotechnology. Anti-phosphorylated pRB (Ser 795) and anti-pRB C-terminal antibodies were purchased from Cell Signaling Technology. Anti-ERK1/2 and anti-active ERK antibodies were purchased from Promega Corporation. Anti-AKT and anti-active AKT antibodies were purchased from Cell Signaling Technology.

Cell cycle analysis. A549 cells were incubated for $24 \mathrm{~h}$ in $1 \mathrm{ml}$ of DMEM containing 10\% FCS using 6-well flat bottom multiplates (Sumitomo Bakelite Co., Tokyo, Japan). After 24 h, growth media was removed. Cells were pretreated with or without $10 \mu \mathrm{M}$ of dexamethasone for $12 \mathrm{~h}$. After dexamethasone containing growth media was removed, $5 \mathrm{nM}$ of paclitaxel was added to each well. Cells were incubated for $48 \mathrm{~h}$ further. The cells were washed, collected by trypsinization and resuspended in $1 \mathrm{ml}$ phosphate-buffered saline (PBS). The cells were fixed in ice-cold $70 \%$ ethanol overnight at $4{ }^{\circ} \mathrm{C}$ and resuspended in $0.5 \mathrm{ml}$ of PBS containing RNase A $(1 \mu \mathrm{g} / \mathrm{ml})$. Cell fluorescence was analyzed on a Becton FACScan, using cell Quest software (Becton Dickinson, Mountain View, CA).

MTT assay. The effects of dexamethasone on the cell proliferation in A549 cells were measured by MTT assay. Cells were counted with a hematocytometer, $1 \times 10^{3}$ cells were incubated in $100 \mu \mathrm{l}$ medium for $24 \mathrm{~h}$ using 96-well flat bottom multiplates (Nalge Nunc International K.K., Denmark). After $24 \mathrm{~h}$, cells were treated with dexamethasone at 0-100 $\mu \mathrm{M}$ for 24 and $48 \mathrm{~h}$. Then, $20 \mu \mathrm{g}$ of MTT in $10 \mu \mathrm{l}$ PBS was added to each well and incubation was performed for an additional $4 \mathrm{~h}$. Thereafter, $100 \mu \mathrm{l}$ of $0.04 \mathrm{~N} \mathrm{HCl}$ in 2-propanol was added and incubated overnight in order to solubilize the MTT formazan crystal. The absorbance of each well was measured at a 570-nm wavelength (reference $650 \mathrm{~nm}$ ) using a scanning multi-well spectrophotometer (MPR A4i, Tosoh Co., Tokyo, Japan).

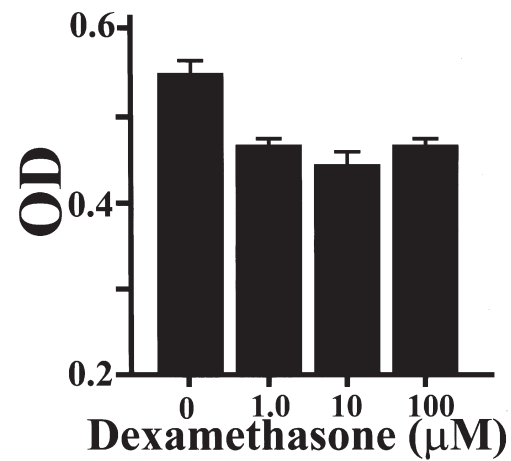

Figure 1. Effect of dexamethasone on the proliferation in A549 cells. A549 cells were treated with the indicated concentrations of dexamethasone for $48 \mathrm{~h}$. The cell count was assessed by MTT assay and expressed as the optical density (OD). Data are presented as the mean \pm SD of three separate experiments.

The cytotoxic activity of paclitaxel was measured by MTT assay as described above. A549 cells were exposed to various concentrations of paclitaxel in the presence or absence of pretreatment with dexamethasone for $12 \mathrm{~h}$ or concurrent treatment with $50 \mu \mathrm{M}$ of PD98059 and $25 \mu \mathrm{M}$ of LY294002.

\section{Results}

Effect of dexamethasone on proliferation in A549 cells. To investigate whether dexamethasone effects proliferation, A549 cells were treated with $0-100 \mu \mathrm{M}$ dexamethasone for 24 and $48 \mathrm{~h}$. Although the proliferation of A549 cells did not differ with dexamethasone treatment for $24 \mathrm{~h}$ (data not shown), cell proliferation was inhibited clearly at dexamethasone concentrations $>1.0 \mu \mathrm{M}$ after 48 -h treatment (Fig. 1). Since $10 \mu \mathrm{M}$ of dexamethasone exerted maximum growth-inhibitory effects on A549, this concentration was adopted for the following experiments.

Effects of dexamethasone pretreatment on paclitaxel-induced cytotoxic activity in A549 cells. Then, we investigated the effect of dexamethasone pretreatment on paclitaxel-induced cytotoxicity. A549 cells were pretreated with or without $10 \mu \mathrm{M}$ dexamethasone for $12 \mathrm{~h}$ and exposed to various concentrations of paclitaxel for $72 \mathrm{~h}$. The cytotoxic effects were evaluated by MTT assay. As shown, pretreatment with $10 \mu \mathrm{M}$ of dexamethasone clearly inhibited the cytotoxic activity of paclitaxel (Fig. 2).

Effects of dexamethasone and palcitaxel on cell cycle distribution in A549 cells. For the purpose of linking the effect of cell cycle distribution and the biological response to dexamethasone and paclitaxel, we performed DNA content analysis by propidium-iodine staining in A549 cells. A549 cells were treated with $10 \mu \mathrm{M}$ of dexamethasone for $12 \mathrm{~h}$, $5 \mathrm{nM}$ of paclitaxel for $48 \mathrm{~h}$ or their combination. DNA ploidy analysis by flow cytometry is shown in Fig. 3. G1-phase cells increased slightly after treatment with dexamethasone for $12 \mathrm{~h}$ compared with that of the control (Fig. 3A and B). Even after 48-h treatment with dexamethasone, sub-G1 cell populations did not increase (data did not shown). After paclitaxel treatment for 48 h, G1-phase cells disappeared, and sub-G1 cell 


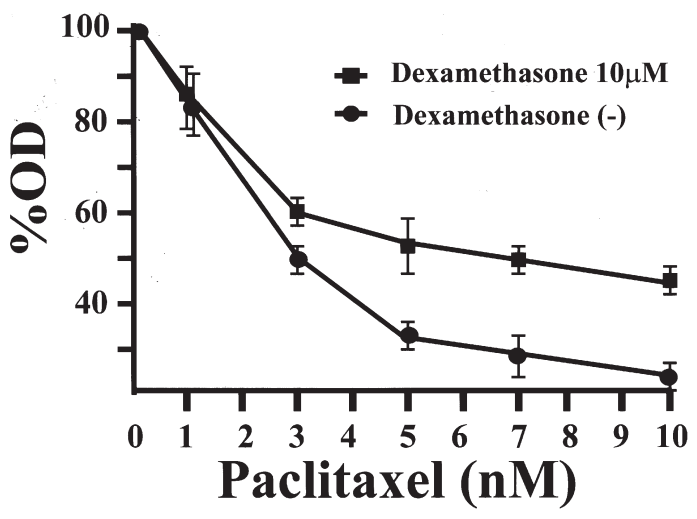

Figure 2. Effects of dexamethasone on paclitaxel-induced cytotoxicity in A549 cells. A549 cells were pretreated with or without $10 \mu \mathrm{M}$ dexamethasone for $12 \mathrm{~h}$ and exposed to various concentrations of paclitaxel for $72 \mathrm{~h}$. The cytotoxicity was assessed by MTT assay and expressed as the percentage of optical density (\% OD) in reference to the OD of paclitaxel-untreated cells. Data are presented as the mean \pm SD of three separate experiments.

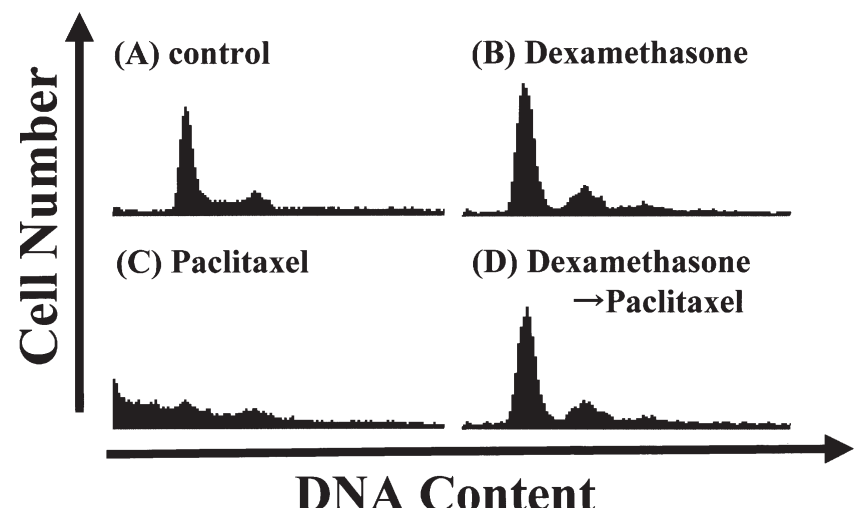

Figure 3. Flow cytometric analysis of cell cycle distribution in A549 cells treated with paclitaxel and dexamethasone. A549 cells were treated with $10 \mu \mathrm{M}$ of dexamethasone for $12 \mathrm{~h}$ and normal medium for $48 \mathrm{~h}(\mathrm{~B}), 5 \mathrm{nM}$ of paclitaxel for $48 \mathrm{~h}(\mathrm{C})$, or the alternative-combination of each drug (dexamethasone pretreatment for $12 \mathrm{~h}$ and treatment with paclitaxel for 48 h) (D). Cells were fixed, stained and analyzed as described in Materials and methods.

populations increased significantly, indicating apoptosis by paclitaxel (Fig. 3C). However, combination of paclitaxel with dexamethasone pretreatment for $12 \mathrm{~h}$ completely inhibited paclitaxel-induced apoptosis as manifested by a reduced number of cells in the sub-G1 population of A549 cells (Fig. 3D). A significant proportion of the remaining cells were still in the G1 phase, indicating the inhibition of cell cycle progression induced by the dexamethasone pretreatment.

Effects of dexamethasone and paclitaxel on $\mathrm{pRB}$ phosphorylation status in A549 cells. We investigated the effect of dexamethasone and paclitaxel on pRB phosphorylation. Since treatment with $5 \mathrm{nM}$ of paclitaxel strongly affected the pRB phosphorylation status of NSCLC cells in our previous study (17), this concentration was used in the present study. Although treatment with paclitaxel did not change the phosphorylated status of pRB in A549 cells, treatment with $10 \mu \mathrm{M}$ of dexamethasone for $12 \mathrm{~h}$ completely blocked $\mathrm{pRB}$ phosphorylation and it was not altered with $5 \mathrm{nM}$ of paclitaxel (Fig. 4). These

$\begin{array}{lllll}\text { Paclitaxel } & - & + & - & + \\ \text { Dexamethasone } & - & - & + & +\end{array}$

ppRB

(Ser 795)

pRB

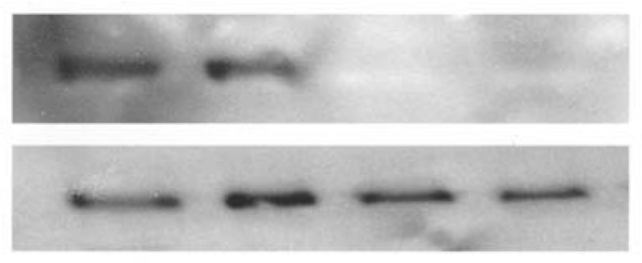

(IP: RB IF-8)

Figure 4. Effect of dexamethasone on the phosphorylation of pRB in A549 cells. A549 cells were treated with or without $5 \mathrm{nM}$ of paclitaxel and $10 \mu \mathrm{M}$ of dexamethasone for $24 \mathrm{~h}$, and pRB was immunoprecipitated from $1 \mathrm{mg}$ of total cellular protein by anti-pRB (IF8) antibody and subjected to Western blot analysis with anti-phosphorylated pRB (ppRB) (upper panel) or anti-pRB C-terminal antibody (lower panel) as described in Materials and methods.

data indicate that pretreatment with dexamethasone for $12 \mathrm{~h}$ before paclitaxel treatment dephosphorylates pRB and then inhibits paclitaxel-induced cytotoxicity in A549 cells.

Effects of ERK and AKT inhibitor on the phosphorylation of $p R B$, and effects of dexamethasone on the activity of ERK and AKT in A549 cells. To explore the role of ERK and AKT in the dexamethasone-induced dephosphorylation of $\mathrm{pRB}$, the effect of specific inhibitor of ERK, PD98059, or AKT, LY294002 was evaluated in A549 cells. Treatment with $50 \mu \mathrm{M}$ of PD98059 and $25 \mu \mathrm{M}$ of LY294002 suppressed the phosphorylation of pRB, indicating that, in A549 cells, ERK and AKT activation is essential for pRB phosphorylation.

Then, using a specific antibody to detect the active form of ERK and AKT, we evaluated the effects of dexamethasone on the activity of these kinases in A549 cells. In A549 cells, the level of phosphorylated ERK and AKT did not change in response to paclitaxel, and this ERK and AKT activation was blocked in the presence of $50 \mu \mathrm{M}$ of PD98059 and $25 \mu \mathrm{M}$ of LY294002, respectively. The dexamethasone treatment inhibited ERK phosphorylation to a similar level as did PD98059 treatment (Fig. 5B). On the other hand, the level of phosphorylated AKT did not change after dexamethasone treatment (Fig. 5C).

Effects of ERK and AKT inhibitor on paclitaxel-induced cytotoxicity in A549 cells. To confirm the importance of pRB dephosphorylation in the antagonistic effect of dexamethasone on paclitaxel-induced cytotoxicity, we assessed the effect of PD98059 and LY294002 on paclitaxel-induced cytotoxicity. A549 cells were treated with paclitaxel for $72 \mathrm{~h}$ in the presence or absence of $50 \mu \mathrm{M}$ PD98059 or $25 \mu \mathrm{M}$ LY294002. The cytotoxic effects were evaluated by MTT assay. As shown, $50 \mu \mathrm{M}$ PD98059 and $25 \mu \mathrm{M}$ LY294002, which were sufficient to block pRB phosphorylation, clearly inhibited paclitaxel-induced cytotoxicity in A549 cells (Fig. 6).

\section{Discussion}

This in vitro study was carried out in order to clarify the effect of glucocorticoid premedication on paclitaxel-induced cytotoxicity to NSCLC cells and the underlying mechanism 
A

$\begin{array}{lllllll}\text { PD98059 } & - & + & - & - & + & - \\ \text { LY294002 } & - & - & + & - & - & + \\ \text { Paclitaxel } & - & - & - & + & + & + \\ \text { PpRB } & & & & & & \\ \text { (Ser 795) } & & & & & \end{array}$

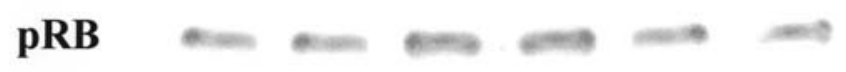

(IP: RB IF-8)

B

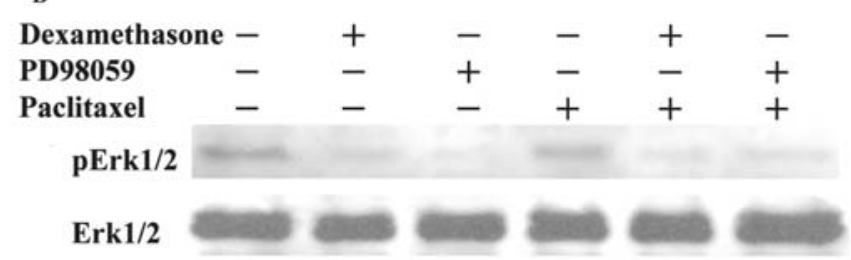

C

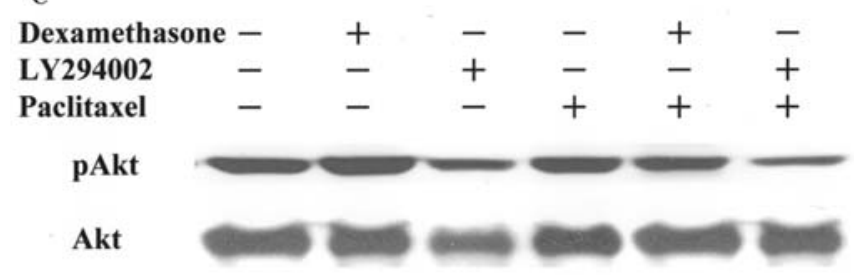

Figure 5. Effects of ERK and AKT inhibitor on the phosphorylation of pRB, and effects of dexamethasone on the activity of ERK and AKT in A549 cells. (A) A549 cells were treated with or without $5 \mathrm{nM}$ of paclitaxel, $50 \mu \mathrm{M}$ of PD98059 and $25 \mu \mathrm{M}$ of LY294002 for $24 \mathrm{~h}$, and pRB was immunoprecipitated from $1 \mathrm{mg}$ of total cellular protein by anti-pRB (IF8) antibody and subjected to Western blot analysis with anti-phosphorylated pRB (ppRB) (upper panel) or anti-pRB C-terminal antibody (lower panel) as described in Materials and methods. (B) A549 cells were incubated with $5 \mathrm{nM}$ paclitaxel for $12 \mathrm{~h}$ in the presence or absence of dexamethasone $(10 \mu \mathrm{M})$ or PD98059 $(50 \mu \mathrm{M})$, and $50 \mu \mathrm{g}$ of total cellular protein from cell lysate was subjected to Western blot analysis with anti-active ERK (pERK1/2) (upper panel) or anti-ERK1/2 (lower panel) as described in Materials and methods. (C) A549 cells were incubated with $5 \mathrm{nM}$ paclitaxel for $12 \mathrm{~h}$ in the presence or absence of dexamethasone $(10 \mu \mathrm{M})$ or LY294002 $(25 \mu \mathrm{M})$, and $50 \mu \mathrm{g}$ of total cellular protein from cell lysate was subjected to Western blot analysis with anti-active AKT (pAKT) (upper panel) or anti-AKT (lower panel) as described in Materials and methods.

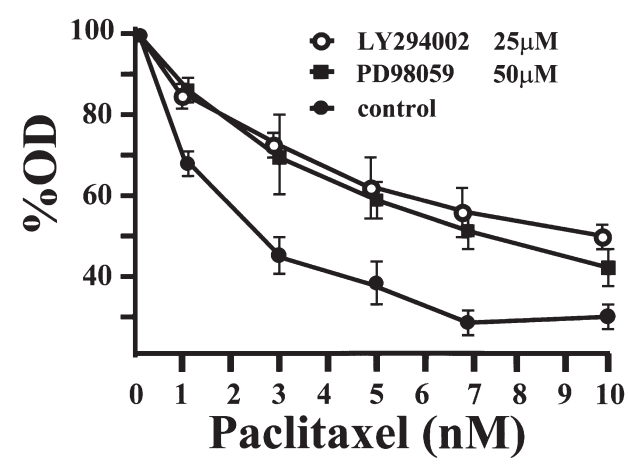

Figure 6. Effects of ERK and AKT inhibitor on paclitaxel-induced cytotoxicity in A549 cells. A549 cells were treated with various concentrations of paclitaxel in the presence or absence of PD98059 $(50 \mu \mathrm{M})$ or LY294002 $(25 \mu \mathrm{M})$ for $72 \mathrm{~h}$. The cytotoxicity was assessed by MTT assay and expressed as the percentage of optical density (\% OD) in reference to the OD of paclitaxel-untreated cells. by which glucocorticoid interferes with the action of paclitaxel. Our observations in the present study suggest that the ERK, but not AKT, inhibition and the subsequent dephosphorylation of $\mathrm{pRB}$ by pretreatment with dexamethasone are important mechanisms of its antagonistic effect on paclitaxel-induced cytotoxicity.

Using A549 cells as a model system of NSCLC, we examined the effects of dexamethasone on cell proliferation, phosphorylation status of pRB and paclitaxel-induced cytotoxicity. Treatment with dexamethasone suppressed the growth of A549 cells. Judging from the results from MTT assay and flow cytometric analysis, this growth suppression by dexamethasone is attributable to cytostatic but not cytotoxic effects. The dephosphorylation of $\mathrm{pRB}$ by dexamethasone can be regarded as a main mechanism of the growth inhibitory effect since its phosphorylation is essential for S-phase entry from G1 phase in the cell cycle (16).

Previously, we reported that paclitaxel activates ERK and subsequently phosphorylates pRB in a cell-specific manner, and proposed that $\mathrm{pRB}$ phosphorylation by pactlitaxel may enhance the sensitivity to it (17). Although paclitaxel itself did not affect pRB phosphorylation in A549 cells, the proliferationinhibitory effect and pRB dephosphorylation by dexamethasone promoted us to speculate that the combination of paclitaxel with dexamethasone may be antagonistic.

After the initial report of hypersensitive reactions of paclitaxel to the National Cancer Institute, it was recommended for all patients receiving paclitaxel to be given prophylactic therapy including dexamethasone. Since then, dexamethasone was administered 12-14 h before paclitaxel administration. So we used dexamethasone $12 \mathrm{~h}$ before treatment with paclitaxel (5). To approximate clinical application, we exposed cells to dexamethasone for $12 \mathrm{~h}$ before paclitaxel treatment. Pretreatment of A549 cells with dexamethasone suppressed the effect of paclitaxel. Judging from the decrease of sub-G1 population in dexamethasone-pretreated cells compared with those with paclitaxel alone, dexamethasone was thought to inhibit paclitaxel-induced apoptosis. In general, paclitaxel acts on cells in the $\mathrm{M}$ phase and induces apoptosis. Accordingly, since a major cell fraction were still in the G1 phase even after paclitaxel treatment in dexamethasone-pretreated cells, it is natural to speculate that G1-arrest induced by pRB dephosphorylation may be an important mechanism by which dexamethasone suppressed the effect of paclitaxel.

To confirm this speculation, we utilized ERK (PD98059) and AKT (LY294002) inhibitors. ERK activation potentiates the cyclin D expression and inactivates $\mathrm{p} 27^{\mathrm{Kip} 1}$ cell cycle inhibitor protein $(18,19)$. AKT suppresses p2 $1^{\mathrm{WAF} 1 / \mathrm{CIP} 1}$ and $\mathrm{p} 27^{\mathrm{Kip} 1}$ function through phosphorylation $(20,21)$, leading to pRB phosphorylation. Thus, the suppression of these two kinases should lead to the dephosphorylation of $\mathrm{pRB}$. As expected, PD98059 and LY294002 effectively suppressed pRB phosphorylation in A549 cells. Dexamethasone (10 $\mu \mathrm{m})$ suppressed ERK activity as well as $50 \mu \mathrm{M}$ PD98059, although it did not affect AKT activity. Furthermore, the combinations of paclitaxel with PD98059 or LY294002 were similarly antagonistic. These observations are in accordance with our previous study that proposed that $\mathrm{pRB}$ dephosphorylation confers paclitaxel resistance to cancer cells (17). We concluded that, in A549 cells, the antagonistic effect of dexamethasone 
pretreatment on paclitaxel-induced cytotoxicity is attributable to the ERK suppression and subsequent pRB dephosphorylation.

Several previous studies reported that inhibition of ERK and AKT pathway enhanced paclitaxel-induced cytotoxicity (22-26). However, these observations are not necessarily general. Bacus et al observed that when PD98059 and paclitaxel were applied simultaneously, antagonistic effects were observed (27), in accordance with our result obtained in A549 cells. Mitsuuchi et al reported that PI3K/AKT signaling did not alter the paclitaxel-induced cytotoxicity, suggesting cell death induced by paclitaxel proceeds independently of cell protective effects of this pathway (21). Both ERK and AKT pathway mediate cell growth-promoting and anti-apoptotic signaling (28-30). Many cancer cells have abnormality of cell cycle regulators including $\mathrm{pRB}, \mathrm{CDKs}$, and $\mathrm{CDK}$ inhibitors (31), and deviate from the normal regulation of cell cycle. In that case, the suppression of ERK and AKT may enhance paclitaxel-induced apoptosis without affecting the cell cycle through the inhibition of the anti-apoptotic effect which is another function of ERK and AKT. On the other hand, in the case that the suppression of ERK and AKT leads to pRB dephosphorylation and G1-arrest, it is possible that inhibition of these kinases antagonizes paclitaxel-induced cytotoxicity through the decrease of paclitaxel-sensitive $M$ phase cell fraction during paclitaxel exposure. The present study raised the possibility that dexamethasone pretreatment antagonizes paclitaxel-induced cytotoxicity, at least, in a fraction of cancer cells through ERK suppression and subsequent pRB dephosphorylation.

A new analogue and formulation of paclitaxel are being developed $(32,33)$, leading to the decrease or removal of polyoxyethylatedcastor oil that causes hypersensitivity reactions in the use of conventional paclitaxel preparation. Even if these drugs have the same activity against cancer cells as paclitaxel, it may be possible that the omission of glucocorticoid pretreatment will lead to higher effectiveness. Our observation in this study supports this possibility and promotes the development of chemotherapies using a new generation of taxane that obviates glucocorticoid premedication.

In conclusion, the present study demonstrated that pretreatment with dexamethasone before paclitaxel exposure antagonized paclitaxel-induced cytotoxicity through inhibition of ERK and pRB phosphorylation in A549 cells. These observations support the development of new generation taxane-based chemotherapy without glucocorticoid premedication.

\section{References}

1. Non-small Cell Lung Cancer Collaborative Group: Chemotherapy in non-small cell lung cancer: a meta-analysis using updated data on individual patients from 52 randomised clinical trials. BMJ 311: 899-909, 1995.

2. Crino L: Combined platinum containing treatment in NSCLC. Lung Cancer 38 (suppl. 3): S51-S52, 2002.

3. Schiller JH, Harrington D, Belani CP, et al: Comparison of four chemotherapy regimens for advanced non-small-cell lung cancer. N Engl J Med 346: 92-98, 2002.

4. Manfredi JJ, Parness J and Horwitz SB: Taxol binds to cellular microtubules. J Cell Biol 94: 688-696, 1982.

5. Weiss RB, Donehower RC, Wiernik PH, et al: Hypersensitivity reactions from taxol. J Clin Oncol 8: 1263-1268, 1990.
6. Gennari A, Salvadori B, Tognoni A and Conte PF: Rapid intravenous premedication with dexamethasone prevents hypersensitivity reactions to paclitaxel. Ann Oncol 7: 978-979, 1996

7. Quock J, Dea G, Tanaka M, Gandara D, Lara P and Lau D: Premedication strategy for weekly paclitaxel. Cancer Invest 20: 666-672, 2002.

8. Rogatsky I, Trowbridge JM and Garabedian MJ: Glucocorticoid receptor-mediated cell cycle arrest is achieved through distinct cell-specific transcriptional regulatory mechanisms. Mol Cell Biol 17: 3181-3193, 1997.

9. Sanchez I, Goya L, Vallerga AK and Firestone GL: Glucocorticoids reversibly arrest rat hepatoma cell growth by inducing an early G1 block in cell cycle progression. Cell Growth Differ 4: 215-225, 1993.

10. Corroyer S, Nabeyrat E and Clement A: Involvement of the cell cycle inhibitor CIP1/WAF1 in lung alveolar epithelial cell growth arrest induced by glucocorticoids. Endocrinology 138: 3677-3685, 1997.

11. Ramalingam A, Hirai A and Thompson EA: Glucocorticoid inhibition of fibroblast proliferation and regulation of the cyclin kinase inhibitor p21Cip1. Mol Endocrinol 11: 577-586, 1997.

12. Baghdassarian N, Catallo R, Mahly MA, et al: Glucocorticoids induce $\mathrm{G} 1$ as well as S-phase lengthening in normal human stimulated lymphocytes: differential effects on cell cycle regulatory proteins. Exp Cell Res 240: 263-273, 1998.

13. Rogatsky I, Hittelman AB, Pearce D and Garabedian MJ: Distinct glucocorticoid receptor transcriptional regulatory surfaces mediate the cytotoxic and cytostatic effects of glucocorticoids. Mol Cell Biol 19: 5036-5049, 1999.

14. Mihara K, Cao XR, Yen A, et al: Cell cycle-dependent regulation of phosphorylation of the human retinoblastoma gene product. Science 246: 1300-1303, 1989.

15. Shimizu E, Coxon A, Otterson GA, et al: RB protein status and clinical correlation from 171 cell lines representing lung cancer, extrapulmonary small cell carcinoma, and mesothelioma. Oncogene 9: 2441-2448, 1994.

16. Harbour JW and Dean DC: Rb function in cell-cycle regulation and apoptosis. Nat Cell Biol 2: E65-E67, 2000.

17. Suyama H, Igishi $\mathrm{T}$, Sano $\mathrm{H}$, et al: ERK activation and subsequent RB phosphorylation are important determinants of the sensitivity to paclitaxel in lung adenocarcinoma cells. Int $\mathbf{J}$ Oncol 24: 1499-1504, 2004.

18. Kawada M, Yamagoe S, Murakami Y, Suzuki K, Mizuno S and Uehara Y: Induction of p27Kip1 degradation and anchorage independence by Ras through the MAP kinase signaling pathway. Oncogene 15: 629-637, 1997.

19. Lenferink AE, Busse D, Flanagan WM, Yakes FM and Arteaga CL: ErbB2/neu kinase modulates cellular p27(Kip1) and cyclin D1 through multiple signaling pathways. Cancer Res 61: 6583-6591, 2001.

20. Brennan P, Babbage JW, Burgering BM, Groner B, Reif K and Cantrell DA: Phosphatidylinositol 3-kinase couples the interleukin-2 receptor to the cell cycle regulator E2F. Immunity 7: 679-689, 1997.

21. Mitsuuchi Y, Johnson SW, Selvakumaran M, Williams SJ, Hamilton TC and Testa JR: The phosphatidylinositol 3-kinase/ AKT signal transduction pathway plays a critical role in the expression of $\mathrm{p} 21 \mathrm{WAF} 1 / \mathrm{CIP} 1 / \mathrm{SDI} 1$ induced by cisplatin and paclitaxel. Cancer Res 60: 5390-5394, 2000.

22. MacKeigan JP, Collins TS and Ting JP: MEK inhibition enhances paclitaxel-induced tumor apoptosis. J Biol Chem 275: 38953-38956, 2000.

23. Seidman R, Gitelman I, Sagi O, Horwitz SB and Wolfson M: The role of ERK $1 / 2$ and p38 MAP-kinase pathways in taxolinduced apoptosis in human ovarian carcinoma cells. Exp Cell Res 268: 84-92, 2001.

24. MacKeigan JP, Taxman DJ, Hunter D, Earp HS III, Graves LM and Ting JP: Inactivation of the antiapoptotic phosphatidylinositol 3-kinase-Akt pathway by the combined treatment of taxol and mitogen-activated protein kinase kinase inhibition. Clin Cancer Res 8: 2091-2099, 2002.

25. Hu L, Hofmann J, Lu Y, Mills GB and Jaffe RB: Inhibition of phosphatidylinositol 3'-kinase increases efficacy of paclitaxel in in vitro and in vivo ovarian cancer models. Cancer Res 62: 1087-1092, 2002.

26. Shingu T, Yamada K, Hara N, et al: Synergistic augmentation of antimicrotubule agent-induced cytotoxicity by a phosphoinositide 3-kinase inhibitor in human malignant glioma cells. Cancer Res 63: 4044-4047, 2003. 
27. Bacus SS, Gudkov AV, Lowe M, et al: Taxol-induced apoptosis depends on MAP kinase pathways (ERK and p38) and is independent of p53. Oncogene 20: 147-155, 2001.

28. Peyssonnaux $\mathrm{C}$ and Eychene A: The Raf/MEK/ERK pathway: new concepts of activation. Biol Cell 93: 53-62, 2001

29. Osaki M, Oshimura M and Ito H: PI3K-Akt pathway: its functions and alterations in human cancer. Apoptosis 9: 667-676, 2004.

30. Tsuruo T, Naito M, Tomida A, et al: Molecular targeting therapy of cancer: drug resistance, apoptosis and survival signal. Cancer Sci 94: 15-21, 2003.
31. Osada $\mathrm{H}$ and Takahashi T: Genetic alterations of multiple tumor suppressors and oncogenes in the carcinogenesis and progression of lung cancer. Oncogene 21: 7421-7434, 2002.

32. Hidalgo M, Aylesworth C, Hammond LA, et al: Phase I and pharmacokinetic study of BMS-184476, a taxane with greater potency and solubility than paclitaxel. J Clin Oncol 19: 2493-2503, 2001.

33. Gradishar WJ, Tjulandin S, Davidson N, et al: Phase III trial of nanoparticle albumin-bound paclitaxel compared with polyethylated castor oil-based paclitaxel in women with breast cancer. J Clin Oncol 23: 7794-7803, 2005. 